\title{
Under Siege: The Rise of Right-Wing Populism or has the Demos Become Crazy?
}

\author{
Paul D. Scott' \\ https://orcid.org/0000-0003-3263-7615 \\ I - Catholic University of Lille \\ Paris, France
}

Abstract: The title of this paper is a play on words re-working the word democracy into demos-crazy. This re-working however is not a joke as the election of authoritarian illiberal candidates in the United States, the Philippines, Hungary, Turkey and Brazil (to name but a few) has called into question the future shape of politics. Electoral politics is under siege by new parties as well as spontaneous movements. There are fundamental questions which need to be addressed. What are the reasons for the rise of right-wing populism? Is populism undemocratic? What has been the role of social media and ICTs in helping to create a new political spectrum? Politically and socially what does it mean if we have entered a post-truth age? The demos has not become crazy but democracy is certainly in retreat. This paper argues that liberalism needs to construct an honest counter-narrative in contrast to the fear-mongering and false nostalgia of the right. The rhetoric of the right is opportunistic, but it would be a fatal mistake to dismiss its appeals. After all, it has won elections. The demos is not crazy, but has been ignored and in many cases left behind. Positive populism is grounded in human dignity and fairness. This is the essence of democracy.

Keywords: populism; fake-news; social media; cyber-utopia; cyber-dystopia; democracy; authoritarianism.

Resumo: Sob cerco: a ascensão do populismo de direita ou será que o Demos ficou doido? O título deste artigo faz um trocadilho com as palavras democracia e "demo-loucura". No entanto, tal trocadilho não é uma brincadeira, como as eleições dos candidatos iliberais e autoritários nos Estados Unidos, Filipinas, Hungria, Turquia e Brasil (para nomear apenas alguns), que têm colocado em questão o futuro modelo da política. As políticas eleitorais estão sob o cerco de novos partidos bem como de movimentos espontâneos. Há questões fundamentais que precisam ser pontuadas. Quais são as razões para o aumento do populismo de direita? O populismo é anti-democrático? Qual tem sido o papel das mídias sociais e dos ICTs para criar um novo espectro político? Política e socialmente, o que significa termos entrado e uma era da pós-verdade? A demos não se tornou alucinante, mas a democracia 
certamente está em retrocesso. Este artigo argumenta que o liberalismo precisa construir uma contra narrativa em contraste à arrogância do medo e à falsa nostalgia da direita. A retórica da direita é oportunista, mas seria um erro fatal desmerecer sua aparência. Afinal, ela tem ganhado eleições. A demos não é alucinante, mas tem sido ignorada e, em muitos casos, deixada para trás. O populismo positivo é fundado na dignidade e na justiça humanas. Essa é a essência da democracia.

Palavras-chaves: populismo; fake-news; mídias sociais; ciber-utopia; ciber-distopia; democracia; autoritarismo.

"The liberal idea has become obsolete. It has come into conflict with the interests of the overwhelming majority of the population." These comments were made by President Vladimir Putin on 28 June 2019 in an interview with the Financial Times in Osaka, Japan before the G20 Summit. The comments were met with this statement by European Union President Donald Tusk who said: "We are here as Europeans also to firmly and univocally defend and promote liberal democracy... What I find really obsolete are authoritarianism, personality cults, the rule of oligarchs. Even if sometimes they may seem effective." Mr. Putin's comments dominated the news and will have a long half-life.

President Putin's comments bring out in the open the transformation of the political landscape. That Mr. Tusk defends liberalism while heading an organization which many view as undemocratic is indeed ironic.

The list is long so for sake of brevity we are living in a theatre of a Brexit drama (a tragicomedy), the open and unhealed wounds of Donald Trump's election trauma, the danse macabre of the "yellow vests" in France, the nativist posturing backed by illiberal policies of Presidents Erdogan and Orban in Turkey and Hungary, and the shocking adoration for military dictatorships and a rollback of progressive reforms expressed and embraced by the new President of Brazil.

What drives the growing estrangement of southern and eastern Europe from the European Union establishment and protocols? What fuels the anti-EU themes of the recent European elections. In addition, what fed and led to the stunning recent Australian re-election of conservatives? Is this swing to the right a short episodic setback or does it reveal an entrenched battleground of polarization which may end in a defeat of liberal democracy or even in a worst case nightmare scenario of democracy itself?

"If state power and market forces have given birth to the Internet as a new sphere of social and political life, will the same forces take away this life, as they did in Habermas's analysis of the eventual refeudalization of the public sphere (HABERMAS, 1989)'? The "refeudalization of the public sphere" is a frightening and present reality. It is telling that the above quote is from Chinese political dissidents and democracy activists. They understand how their space is being constricted and shaped. China's concerted attacks on the whole

1 From a Chinese dissident website: http://fourgentlemen.blogspot.com/2011/06/single-spark-can-start-prairie-fire. html (access: 28.06.2018) 
range of freedoms are persistent and pervasive ${ }^{2}$. Massive protests in Hong Kong may have at most delayed the stripping away of freedoms guaranteed by the Basic Law ${ }^{3}$.

China is an important test case in whether it is possible for a state to control the internet as well as to create and sustain an authoritarian political regime. The results of this test case, as well as the struggles over values and freedoms, are taking place in Europe, North American and South America and will define this century.

We are in the midst of a resurgent right-wing populism and many democracies are in retreat. This is accompanied by an expansion of information technologies. Knowing the truth, being aware of events, and having access to credible information ensures at least a modicum of state accountability. The ability of citizens to make informed decisions is the essence of democracy in which there is a positive feedback loop between state and the public.

There is a vast difference between totalitarianism and authoritarianism. In fact, the control of information technology aided in the construction of a totalitarian state in Germany but this same expansion of technology also, after 1945, destroyed the possibility of other states to become totalitarian. Perhaps a case could be made for North Korea attempting total control. This being said, paradoxically here we have China attempting to control all forms of digital, electronic and print information. Chinese citizens are free to travel, and information is readily available but what one does with revealed information is a different question. The state would be foolish to assume that its citizens love the leadership and are loyal without question. What the authoritarian state demands is both loyalty and obedience. The collapse of the former East Germany as well as the Soviet Union revealed that while the state was collapsing almost no one came to its defense. It just withered away and died. This collapse, by the way, happened at almost the same time as the massive demonstrations in Tiananmen in Beijing. The use of force then and now was deemed necessary by the leadership the Chinese Communist Party with Deng Xiaoping reportedly stating he was prepared to order the deaths of 200,000 people if this would guarantee twenty years of stability in China ${ }^{4}$.

Under President, Xi Jinping, who was recently reelected with a no term limit, the Chinese government has increasingly eroded their citizen's social and political rights, specifically access to information and their right to freedom of speech and expression. They have done this through controlling ICTs and introducing a Social Credit System (SCS).

The Chinese government has installed a firewall now commonly referred to as "the Great Firewall of China" to block over 10,000 different websites, including Facebook, Twitter and Google. In place of these blocked websites, China created their own mirror

2 For a recent editorial see: https://rsf.org/en/news/chinas-new-world-media-order-christophe-deloire-and-wuerkaixi (access: 28.06.2018)

3 The conventional wisdom regarding Hong Kong was always wrong as commentators always remarked that China would not dare kill the goose which laid golden eggs. It would always be the mainland taking over Hong Kong and not the other way around.

4 This statement is widely quoted and attributed to Deng. See for example: "China's Search for Democracy: The Student and the Mass Movement of 1989". 
versions of these sites that are heavily monitored and controlled by the government. If individuals discuss banned topics or engage in anti-government rhetoric, their accounts can be deleted, and their Internet use suspended.

However, the government does allow for some form of discussion to highlight government practices and policies to be enacted. This is of course heavily monitored.

The SCS is a financial credit ranking system linked with a social behavior rating system, which utilizes data from their country's online and CCTV surveillance system. It is still in its early stages of development and implementation and there are still questions about what exactly it will be once it has been fully implemented. Overall, it aims to create a numerical rating for all individuals and organizations to provide clarity and information for the government and individuals. Parties can be rewarded and punished depending on their rating. For example, a high rating could be rewarded with tax incentives, fast tracked promotions at work and easier access to public housing, while a low rating could see you receive a ban on public transport and flying and your job market limited. An individual's rating is public knowledge and can be accessed by their employer. The system has been criticized as a tool to monitor and control citizens politically, socially and commercially. Individuals and organizations that undertake activities that are seen as creating political division, like partaking in anti-government rhetoric online, illegal protesting or political demonstration can see their rating lowered. Additionally, China has released a mobile app titled "Study The Great Nation" which is a form of social media that includes learning modules about Xi Jinping, the Communist Party, China's history and current events. Individuals receive points for completing modules, which has an influence on an individual's social credit rating. China is in the process of creating a system that rewards those that conform to the Communist Party's values and punishes those that actively oppose or do not participate. Again, this control and manipulation of information and citizen behavior directly impedes with social and political development and furthers their autocratisation. In contrast, there are examples of individuals and the global community utilizing ICTs to assist with political and social development against the Chinese government.

China has taken enormous steps to counter the democratic benefits which digital communication can offer. They control and manipulate the online content of their entire country, minimizing anti-government rhetoric and creating rewards and punishments to incentivize individuals and organizations to act conform. The objective is to legitimize President $\mathrm{Xi}$ Jinping and the Communist Party as an autocratic power, limit political rivalry and control the narrative of the nation. This directly impedes social and political development. Refeudalization of the public sphere is even more amazing within the Chinese context as Mao in his ideology was a cultural iconoclast and a revolutionary who sought to destroy the evils of the old culture. This would not be a "tea party" but a violent struggle and a revolution from below. Seventy years after the founding of the PRC 
we are witness to a revival of repression and control which would have been unimaginable during any former dynasty.

What is amazing about this level of surveillance is the cost. Bloomberg reports:

\begin{abstract}
About 176 million video surveillance cameras monitored China's streets, buildings and public spaces in 2016, versus 50 million in America, according to IHS Markit. In 2017, Xi's government spent an estimated $\$ 184$ billion on domestic security. By 2020, authorities plan to roll out an "omnipresent" nationwide camera network and a social-credit system that tracks personal data on everything from traffic violations to video-game habits (SCHMIDT; FENG, 2019) ${ }^{5}$.
\end{abstract}

The very beginning of this short essay highlights China for obvious reasons which is the possibility or probability but certainly not the desirability that an authoritarian antidemocratic state can sustain its power and not only compete on the world state but perhaps act as a dominant political model which can challenge the liberal West and even dominate. This is critical as after the collapse of the USSR there was an aura of triumphalism especially in Anglo-America and Western Europe. We, the liberal democracies had won, and that consequently history had ended. Looking back, one can recognize the arrogance of these

"End of History" predictions as right-wing, anti-liberal and anti-democratic rhetoric, policies and programs have been resurrected. Democracy itself is in retreat. Freedom House in 2019 begins its report ominously:

In 2018, Freedom in the World recorded the 13th consecutive year of decline in global freedom. The reversal has spanned a variety of countries in every region, from long-standing democracies like the United States to consolidated authoritarian regimes like China and Russia. The overall losses are still shallow compared with the gains of the late 20th century, but the pattern is consistent and ominous. Democracy is in retreat ${ }^{6}$.

It is the triad of nativist populism, enterprising politicians and ICT's which are leading the anti-liberal charge. But the dominant question must be: why does this negative populism resonate with an electorate? Moreover, the scope and the diversity of this global electorate ranges from the so-called advanced mature democracies, to post-communist states, to Islamic states, to post-military governments in Latin America.

It is too facile to talk and analyze political transitions. After all, aren't all political systems dynamic and in transition? It is more instructive to frame these movements in terms of "exits." Decades of colonial, military rule and/or one-party rule and then overnight there is a transition to democracy? What about all those power structures? Fascist judges are transformed into democratic ones? Police and security forces — do they even change their

5 Surveillance is also big business as Bloomberg also reports that the companies providing the monitoring are worth more than 12 billion dollars.

6 https://freedomhouse.org/report/freedom-world/freedom-world-2019/democracy-in-retreat (access: 28.06.2019) 
uniforms? School textbooks need to be re-written and teachers retrained. Attitudes and behaviors, do they change overnight? A good historian could delineate prewar and wartime but when exactly does the postwar era end? The same can be said for colonialism. When are the effects of colonialism evaporated? To phrase this another way, a formal occupation era end but what about an occupation mentality - the residual effects? Direct military rule may have been overthrown but has the military been democratized? Paramilitaries are of course a separate set of challenges. Nostalgia, which is constructed and selective memory, can feed negative populism which harkens back to a "glorious" past and also posits a rich future.

These are critical questions and they lead us to the conclusion that the battle over values and ideals are not settled and that this space is being filled by both positive populists and negative populists.

The state in the present must construct, promote and implement what I would call a transfer culture of mechanisms. These mechanisms allow the state to focus on its goals - its goal culture. The whole 20th century was a battle over these mechanisms. The battle of ideology or "isms." It is instructive that many of the isms are connected with names. Mao, Lenin, Stalin, Hitler, Peron (or also called "Justicialism"). Some of these isms were destroyed by warm others by economics. To repeat, it may have seemed that after the collapse of the Soviet Union the only two isms left standing: one was liberalism and the other capitalism.

Today both capitalism and liberalism are under siege. The reasons are complex, but it is not an overstatement to say that at the end of the second decade of this new millenium, the shaping of justice is one of the core rallying points of populist rhetoric. And this battle will be shaped in large part in the virtual realm of social media.

We have come a long way since writers commented on the upcoming "cyber-utopia" (CHATFIELD, 2011) - The road from a much over-hyped cyber-utopia to cyper-sceptics to a possible cyberdystopia is very short. Watch Steven Jobs introducing the iPhone in 2007. The audience is almost orgiastic ${ }^{7}$. The first iPhone on the market was only 12 years ago. ITU reports:iPhones "New data show that young people are at the forefront of today's information society: 830 million young people representing more than 80 per cent of the youth population in 104 countries are online ${ }^{\prime \prime}$. A question which I think no one can answer is how new generation raised with iPhones will navigate the social media landscape.

Will they be more attuned to issues of privacy and access than older technology users? Will they be able to discern fake and real news?

7 https://www.youtube.com/watch?v=MnrJzXM7a6o (access: 28.06 .2019 )

8 https://www.itu.int/en/ITU-D/Statistics/Pages/facts/default.aspx For Brazil, “... it is the largest internet market in Latin America and the fourth largest internet market in the world in number of internet users. Projections show internet penetration rate is forecast to grow to about 61 percent in 2021, up from about 56.8 percent in 2016. Overall, Brazilians are heavy internet users. Monthly internet usage in Brazil amounted to 25.7 hours per user in 2016; in comparison, the Latin American average stood at 18.6 hours. Furthermore, 90 percent of Brazilian internet users accessed the internet every day for personal reasons." https:/www.statista.com/ topics/2045/internet-usage-in-brazil/ (access: 28.06.2019) 
What are the ramifications of all this connectivity? This is a massive question but here still at the very beginning of a new era we should be ringing a fire bell in the night as censorship and limits of expression are being implemented ${ }^{9}$. Identity politics is reshaping electoral contests as the battle-lines are drawn between cultural nationalists versus social progressives.

We are in the very early stages of in what we could call the "age of digital resistance". Here is a call for papers for a special issue in a journal devoted to resistance studies:

In many spaces, mobile digital devices and social media are ubiquitous. These devices and applications provide the platforms with which we create, share and consume information.

Many obtain much of their news and social information via the personal screens we constantly carry with us. It is therefore unsurprising that these devices also become integral to acts of social activism and resistance.

This digital resistance is most visible in the virtual social movements found behind hashtags such as \#BlackLivesMatter, \#TakeAKnee, and \#MeToo. However, it would be an oversimplification to limit digital resistance to its most popular expressions. Video sharing on YouTube, Twitter, and Facebook have revealed abuses of police power, racist attacks, and misogyny. The same type of device is used to both record, share, and view instances of abuse. The devices and platforms are also used to organize and coordinate responses, ranging from online naming and shaming, online protests, physical protests. The devices and the platforms are then used to share the protests and their results. More and more the device and the platform are the keyhole through which resistance must fit (MADISON; KLANG, 2019).

The editors suggest that papers could be focused around the following theme:

- $\quad$ Resistance to platforms

- Hashtag activism \& hijacking

- Online protests \& movements

- The use of humor/memes as resistance

- Selfies as resistance

- Globalization of resistance memes

- Ethical implications of digital resistance

- Online ethnography (testimonials/narratives provided by online participants)

- Issues concerning, privacy, surveillance, anonymity, and intellectual property

- Effective rhetorical strategies and aesthetics employed in digital resistance

- Digital resistance: Research methods and challenges

- The role of technology activism in shaping resistance and political agency

- $\quad$ Shaping the digital protest identity

- $\quad$ Policing digital activism

9 This expression was first used by Thomas Jefferson in 1820 when he wrote about the extension of slavery in the United States. 
- Digital resistance as culture

- Virtual resistance communities

- The affordances and limitations of the technological tools for digital resistance (MADISON; KLANG, 2019).

The scope of the themes reveals the degree to which digital activism has become embedded and operationalized. There are extraordinary opportunities as well as challenges to digital resistance.

A constant theme in this essay has been that we are only at the very start of the digital age. The new technologies will be used and misused. The same could be said for the advent of any new form of mass communication whether it be television, radio, or the printing press.

There is an oft-quoted statement, attributed to U.S. Senator Patrick Moynihan, which reads: "Everyone is entitled to their own opinions, but they are not entitled to their own facts" 10 . Facts are facts because they can be easily tested and checked. Two days after the inauguration of Donald Trump as the 45th President of the United States, the U.S. Counselor Kellyanne Conway to the new President during an interview with the television news program "Meet the Press" used the term "alternative facts." Ms. Conway was defending the false statements made by the White House Press Secretary concerning attendance numbers at the inauguration. Conway stated that Sean Spicer was giving "alternative facts" (HIRSCHFELD DAVIS; ROSENBERG, 2017). Despite the severe criticism of the very concept of alternative facts this term has taken on a life of its own and today in many quarters a type of mass cognitive dissonance has taken place where people will misshape a fact to suit their own agenda and then go one step further and defend the fact as absolute objective truth. It is tragic, sad and deeply troubling that old worn out and thoroughly discredited tropes are being resurrected, reused and recycled. It is malevolent social media users who use information technologies to instill and promote division, distrust and hatred.

Is the sub-text of "alternative facts" in fact the newest form of state-sponsored truth? In the new age, it is the skillful rendering and mixing of truth, half-truth and lies. And what is this other than propaganda? The mainstream media are corporations who combine news and entertainment. Ratings translate into advertising revenue. Donald Trump was a master of this and in during the 2016 election received upward of USD $\$ 2$ billion of free coverage (CONFESSORE; YOURICH, 2016). The logo of the venerated New York Times is "All the news that's fit to print" but this begs the question of what is newsworthy and what is suitable (CAMPBELL, 2012).

It is safe to say that we are living in a "post-truth age". Aided by Information Communication Technologies (ICT) an alternative reality is being constructed. This is re-shaping the political landscape and feeding a negative illiberal rightwing populism.

10 Another variant would be: Everyone is entitled to his own opinion, but not his own facts. Quoted in Robert Sobel's review of "Past Imperfect: History According to the Movies", edited by Mark C. Carnes. 
This normative view is not limited to the rightwing, but the left has also reacted and created its own counter narrative. In many countries, political polarization is at its highest levels and the chance of a unifier or even healing is nowhere to be seen ${ }^{11}$.

It is obvious that there is a crisis of electoral democracy. It is further obvious that the quality of electoral democracy is directly related to the quality of political parties. But which political parties? Political parties are voluntary organization whose purpose is to propel candidates into elected office as well as to stake out ideological and public policy positions. This is done through the use of finance which is dependent upon stakeholder donations. Voter identification with the positions of parties is the crucial test of which interest group will dominate at the polls. The performance and more importantly the ability of a political party to adapt, compromise, and shift their position is tactical. What is most critical are questions which need further and deeper investigation - why do groups vote against their own interests and how is public opinion formed? Traditional parties of the left, long the favorite of unionized blue-collar workers in industrialized societies, are declining in significance. In the latest European elections, the British Labour Party got 14 percent of the vote, its lowest since 1910. France's Socialists, a governing party just two years ago, got 6 percent. Germany's Social Democrats, founded in 1880, were at 15 percent. These parties' working-class base has been shrinking. Traditional parties of the right aren't doing much better. Fourteen-year Chancellor Angela Merkel's CDU/CSUat 29 percent. France's Gaullist party was swept aside two years ago by Emmanuel Macron's personal party, which was outpolled by Marine Le Pen's National Rally in the EU elections. Jean-Luc Mélenchon political party La France Insoumise ("Unbowed France") received just $6.31 \%$ of the vote, its worst showing. Britain's Conservatives got 9 percent - the weakest showing ever. In contrast, the Brexit Party, founded just this year, finished number one, with 31 percent.

It may not be premature to comment that in some countries the traditional political parties are in crisis. This author, among others, could easily envision that the United States which has been dominated by the two major political parties could evolve into a 4 or even 5 competitive party system. This would unravel the whole U.S. electoral system at both the Presidential and legislative level.

Brazil's recent election mirrors the crisis of electoral politics in other countries. The populist surge thrives on misinformation, outright lies, fake news, and hearsay. Interestingly, it has been WhatsApp, rather than Facebook or Twitter, which is now the main conduit for heated political debate in Brazil. WhatsApp is completely unfiltered. It is also interesting to note that the print media in Brazil is in crisis. Comparisons are always dangerous but Trump, while in part correct about railing against "fake news" has also done his best to paint the media as distrustful and illegitimate. Bolsonaro has taken even a harder line against press freedom. Reporters Without Borders states:

11 For a recent poll on political polarization in the United States see: https://www.people-press.org/interactives/ political-polarization-1994-2017/(access: 28.06.2019) 
The 2019 World Press Freedom Index compiled by Reporters Without Borders shows how hatred of journalists has degenerated into violence, contributing to an increase in fear. The number of countries regarded as safe, where journalists can work in complete security, continues to decline, while authoritarian regimes continue to tighten their grip on the media....With threats, physical attacks during demonstrations and murders, Brazil continues to be one of Latin America's most violent countries for the media, and journalists are often killed in connection with their work. In most cases, these reporters, radio hosts, bloggers or other information providers were covering stories linked to corruption, public policy or organized crime in small or mid-sized cities, where they are more vulnerable ${ }^{12}$.

Bolsonaro is running a campaign on a handful of promises that strike a chord with many in the Brazilian electorate: a tougher take on crime, radical economic reform to curb unemployment and falling incomes, an ultra-conservative turn in social mores, and unquestioned support for anti-corruption measures. Whether campaign promises can be fulfilled is another issue what is critical is that a message was crafted which had enough resonance for electoral success.

This reduces democracy to an obscene math which is simply: win enough votes to defeat your opponent. Truth is less important than belief. The presumption of guilt trumps due process. Detailed pragmatic policy positions are defeated simply because they are not newsworthy. Instead of strong institutions many voters seek charismatic saviors. Charisma is dangerous. Indeed, many politicians do have vibrant personalities and are gifted public speakers, but media consultants can certainly invent and create a charismatic and often heroic persona. Charisma, after all, is not character but a cult of personality. Focusing on the "savior" ignores the strengthening of the institutions of governance. The call for "leadership" bypasses the complexity of policy making. Issues like taxation, energy, health care and defense when reduced to a few simple slogans do provide solutions but can instead delay implementation.

It is not premature to make some preliminary conclusions concerning the intersection between an atomized and fractured source of unlimited information, the hollowing out of electoral politics, unfiltered responses, and the rise of both left and rightwing populism. Brexit, Trump, Bolsonaro, the yellow vest movement in France, among just a few, are clear and present manifestations of grassroots movements which capitalize on mobilizing an angry citizenry who has been left behind by structural changes in the global economy. Those who vote for the populists, are anti-elite and anti-bureaucracy, distrustful of mainstream political politics, Enterprising politicians have learned how to speak to those who have been left behind by feeding their fears and creating mythologies of a nostalgic past. The combinations of anger, loss, nativism, protection of the "sacred" and the glorification of the state are powerful. It is safe to say that these right-wing movements will not disappear but

12 https://rsf.org/en/2019-world-press-freedom-index-cycle-fear (access: 28.06.2019) 
will widen deepen and spread. It is a borderless movement, but it is also oddly incoherent. The promises of new politicians who appeal to these instincts does not have to be totally coherent and rational as the base if support itself is also free floating and cacophonous. This movement shows that communities which were in the shadows and ignored have constructed vehicles of voice. The yellow vests arose because they not feel listened to and represented. Represented by whom? The traditional political parties as well as the labor unions, The Yellow Vests stake a claim for their voice to be heard. The forces which feed this movement is a stew of many ingredients. In fact, we could say that this movement represents the dropouts of liberal democracy - a failure of elites, an unresponsive bureaucracy, opaque institutions, and liberal economic order which has created wealth but has not distributed it equally. There are gaps which need to be bridged which the European Union must address if it hopes to survive but the medicine, the cure for the malaise of the EU may also end up destroying it as well. There is anger on the streets but as of today this anger has not been organized into a coherent whole with a recognized leader. Tragically we have an example of a populist movement which once swept through Germany.

Undeniably, we are living in a "post truth age" where facts are malleable. The internet is the perfect vehicle for conspiracy theories. The anonymity of the internet allows unfiltered opinion to flow and attract like-minded people. It is not amusing to think of the number of people who believe the American moon landings were a hoax.

\begin{abstract}
A 1999 Gallup poll found that only 6 percent of Americans doubted the Apollo 11 moon landing happened. But - as the 21 st century brought a rise in internet use and a different standard of truth in media - that number has risen, so that Wikipedia's entry on this subject (Moon Landing Conspiracy Theories) now suggests: Opinion polls taken in various locations have shown that between $6 \%$ and $20 \%$ of Americans, $25 \%$ of Britons, and $28 \%$ of Russians surveyed believe that the manned landings were faked (BYRD, 2018).
\end{abstract}

The moon landing hoax is part of a larger challenge of protecting freedom of information and speech but also trying to limit harm. Tolerance of ill - The spread of anti-Semitism and the resurrection of tired old tropes find their way onto the social media and spread like an epidemic. People with hate in their hearts can propagate their beliefs.

Michel Rosenfeld has written: "It seems contradictory to extend freedom of speech to extremists who... if successful, ruthlessly suppress the speech of those with whom they disagree...." (ROSENFELD, 1987) ${ }^{13}$. The limits of tolerance or resolving this paradox is a central dilemma of democracy itself.

Social media and information technology community has not created a cyberutopia but is a perfect tool but for bullies and authoritarians. It is not misinformation but

13 This is also quoted in a Wikipedia article entitled "The Paradox of Tolerance." https://en.wikipedia.org/wiki/ Paradox_of_tolerance\#cite_note-7 (access: 28.06.2019) 
mal-information and deliberate disinformation which is part and parcel of our daily life. The three prefixes attached to the word information: mis, mal and dis are critical lens in which to view the whole architecture of ICTs.

It has been found that democracy is less likely to survive in an environment characterized by misinformation and "fake news", and that when voters are poorly informed, this can lead to the election of incompetent and in many cases corrupt governments (HOLLYER; ROSENDORFF; VREELAND, 2018).

Both the 2016 US election and the 2018 Brazilian elections proved that social media is the perfect tool for spreading "hate speech" and misinformation and mal-information.

Furthermore, the concept of "echo chambers" and "information cocoons" have been increasingly adopted over the past two years and demonstrate ways in which social media can undermine democratic institutions. Facebook itself has noted that one of the most common criticisms of social media is that it creates echo chambers where people only see viewpoints that align and reflect their political beliefs. Algorithmic news feeds used by Facebook and Twitter are designed to bring individuals information that people are more likely to "like", thus placing individuals in a bubble where they only consume information that reflects their social and political values (GRIGONIS, 2018).

These algorithms create an information cocoon which exposes the user to information that supports their own beliefs. This can reinforce extremist beliefs.

There is also a growing partisan and polarized mainstream media. Social media channels thus mirror biases creating information bubbles which tend to overshadow and block out counter-narratives as these have already been dismissed. There develops a selfperpetuating and mutually reinforcing culture. Within this hothouse, opportunities for healthy dialogue wilt. Negative populism will use ICTs to their advantage.

It can be argued that positive populist movements can serve to both highlight and correct flaws in democratic institutions by mobilizing social groups who had previously been marginalized by the political elite.

Populism can be a type of democratic corrective especially if it includes previously marginalized groups as well as lessens the burdens of these we can call "vulnerable".

Populism can improve democracy and the democratic process.

Conflict resolution over policy, after all, can be positive force.

On the other hand, it is also undeniable populism can undermine democracy.

The negative effects of populism can weaken political/judicial/legal institutions and culminate in the undermining of minority rights and protections.

Populism moralizes politics empowering the notion of "the people" to a mythical and sacred position. This fetishism of "the will of the people" is a powerful tool in the hands of undemocratic politicians. One of the most problematic tools employed is the 
referendum or plebiscite. This bypasses institutions and bureaucracies and allows the people to decide complex issues in a simplistic binary Yes/No answer. Nuances are all lost. Of course, referenda and plebiscites can be useful and very democratic, and Switzerland is always used as positive example of direct democracy but minority rights even there are still problematic (DAIGLE, 2014).

The people bypassing established institutions in the name of democracy is a hallmark of populism. Voices long ignored are empowered to speak. This fuels powerful emotions which fill city squares and streets. But these movements also lack leadership and their messages can become diffused and almost incoherent. If everyone is speaking at the same time, then whom do you listen to? Moreover, who does the government negotiate with?

There is no end to the speculation and commentary on the twin crises of democracy and governance.

Elections, open, free and fair, are the essence of democracy, the inescapable sine qua non. As a certified election observer, what is reported are the mechanics and the fairness of the polling day. Polling day is a narrow window that opens for citizens to choose their elected representatives. Therefore proclaiming the mantra that an election is "free and fair" ignores the structural, behavioral, historical, and cognitive rigging which takes places before the election. Governments produced by elections can be inefficient, corrupt, shortsighted, irresponsible, dominated by special interests, violent, and incapable of enacting public policies which serve the common good. It is electoral politics which has been hollowed out.

In conclusion: have the demos become crazy. Are we now living in a world where elections have become a fetish? Democracy is after all a combination of theory, practice, myth and metaphor. Sins of both omission and commission can be undertaken in the name of democracy and military coups in countries like Pakistan can take place to install "real" democracy while the Egyptian military can unseat a sitting President, and some insist it was not a coup. Can there be such a thing a "democratic coup?".

Trump, Orban, Erdogan, Bolsonaro, and Farage can all these politicians and their movements be categorized as an aberration, a betrayal of democratic liberalism? Are the people who vote for the rightwing deluded, misguided by social media and, as Presidential candidate remarked, "basket of deplorable"?

It is easy to list what the populists are against. Anti-bureaucracy, anti-corporation, anticapitalist, anti-elite, anti-the $1 \%$ who dominate wealth, anti-metropole, anti-globalization, anti-traditional political parties and the entrenched political class. The structural changes brought about by neo-liberal economic policies have created a class who deeply feel ignored and left behind by the political elites. The slogans written on back of the yellow vests speak volumes. The back of one yellow vest is addressed to President Macron and declares: "Trickle Down economic theory does not work" while another reads: "I accuse 
this system which fattens the rich and starves the poor"14. In Marxist terms, the rightwing populists are not a lumpenproletariat. They are angry and aware of many of the forces which shape their futures. This author clearly remembers talking with an old textile worker from a small village outside of Faisalabad, Pakistan. Faisalabad, often is referred to as the "Manchester of Pakistan." The woman had almost no formal education. Yet, I was listening to her explain how World Trade Organization rules were negatively impacting her life. Here in France, President Macron instituted a tax on gas and diesel fuel. Macron had no idea how this small extra burden would be enraging.

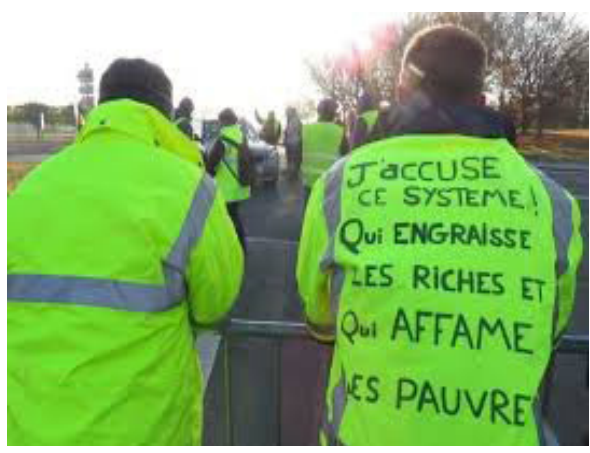

Fig.1. The green vest picture says: "J'accuse ce system qui angraisse les riches et qui affame les pauvres" (I accuse this system which fattens the rich and starves the poor)

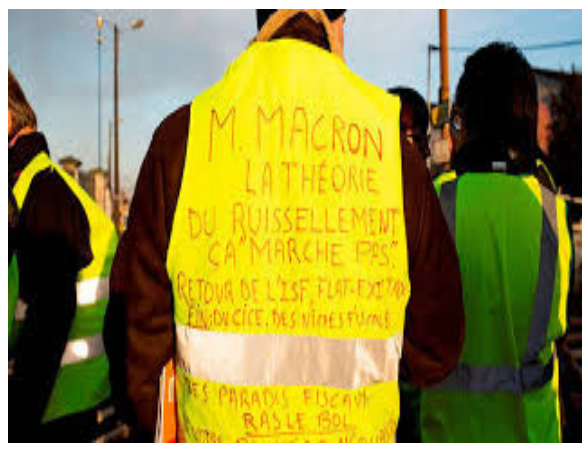

Fig.2. The yellow vest picture says in French: "M. Macron La Théorie du Ruissellement ca marche pas." (M. Macron trickle down theory does not work.)

The underclass may not have advannced degrees in economics and public policy but the elites would be making a grave error to assume that they are unaware and unconcerned. Whether it is Brazil or Pakistan, the real sport of life is not football but politics. People talk, discuss and gossip about politics endlessly. They share information and stories and forge a common consensus. The gossip is endless and delves into even into the personal lives of politicians.

Legitimate and genuine concerns are mixed with hearsay and supposition. ${ }^{15}$ This is of course "street politics" and those in power would be advised to open their ears. Certainly,

14 The internet is replete with images of the Yellow Vests. The slogans written on the back range from the simplest: "Macron démission" (Macron resign) to more complicated statements. It is intriguing that the protestors targeted trickle-down economics https:/www.google.com/search?tbm=isch\&q=yellow+vests+ruissellement +paris\&spell=1 \&sa=X\&ved=0ahUKEwi5m-fq7YvjAhUNT8AKHeLTDNYQBQgoKAA\&biw=1250\&bih=601\& $\mathrm{dpr}=2$ \#imgrc=stvHtg4KWGoiDM: Echoing Zola and the infamous Dreyfus case, I was struck by the power of this Yellow Vest: https://www.google.com/search?biw=1250\&bih=601\&tbm=isch\&sa=1\&ei=INOVXbm LAY2egQbip7OwDQ\&q=yellow+vests $+\mathrm{j} \% 27$ accuse+paris\&oq=yellow+vests $+\mathrm{j} \% 27$ accuse+paris\&gs_l=i mg.3...1739.9527..11756..0.0..0.47.720.20.....0...1..gws-wiz-img.IhGNdFuN3mY. And with appropriate homage to the famous Japanese woodblock artist Hokusai we have the Eiffel tower engulfed: https://www. google.com/search?tbm=isch\&q=yellow+vests+ruissellement+paris\&spell=1\&sa=X\&ved=0ahUKEwi5m-fq7Yv jAhUNT8AKHeLTDNYQBQgoKAA\&biw=1250\&bih=601\&dpr=2 \#imgrc $=8$ AvCSxuS6rrCaM:

15 Once in Pakistan I was listening to a group of men who were talking about how a government minister had watched pornography in his London hotel room. This was all discussed with great vigor and outrage. I wondered how: did they know this? More importantly, they believed it. 
the populists are connected to the street. It is obvious that new art forms emerging from the street inform, give voice and express anger to deep political and social concerns. Rap, dance, theatre, film, graffiti, fashion, tattoos, youtube - the list of populist expression is being enhanced and deepened.

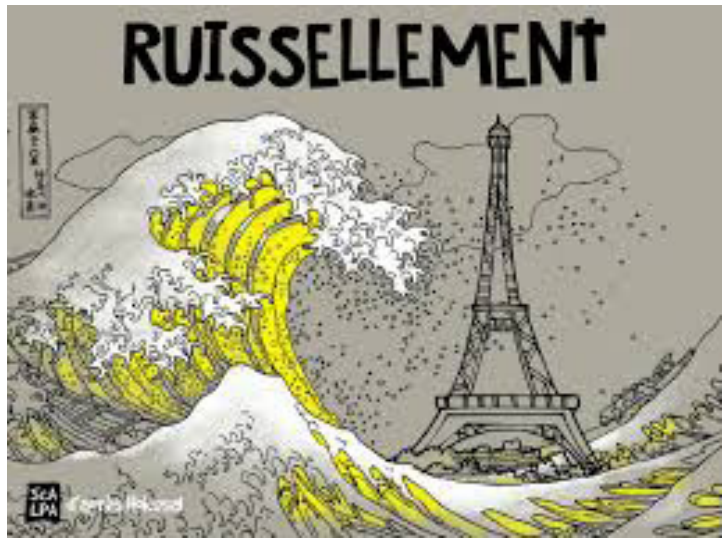

Fig.3. Ruissellement in French means "trickle-down".

It has become a common belief that the young Monsieur Macron is "the president of the rich." Will this anger propel the rightwing to power in France? In the United States will Trump be re-elected? ${ }^{16}$ Will China continue to expand its power and influence while simultaneously limiting freedoms?

This raises the question concerning the sustainability of right-wing populists. While they have demonstrated that they can be elected can they also deliver on their promises? Are right-wing populists good managers? In Brazil,

Bolsonaro's approval rating, which began dropping immediately after he took office on Jan. 1, has declined from $49 \%$ in January to $34 \%$ in late March, according to the Brazilian Institute of Public Opinion and Statistics. That's the lowest ever recorded for a Brazilian president at the 100-day mark (VALE, 2019)

In Turkey, in what has been described as a "major setback" for the ruling party and President Erdogan, Turkey's ruling party has lost control of Istanbul after a re-run of the city's mayoral election. The candidate for the main opposition party, Ekrem Imamoglu, won $54 \%$ of the vote with nearly all ballots counted. As reported by the BBC, "In his victory speech, Mr Imamoglu said the result marked a 'new beginning' for both the city and the country"17. The winner announced: "We are opening up a new page in Istanbul," he said. "On this new page, there will be justice, equality, love"18.

16 Cas Mudde has written about the reasons Trump will win in 2020. See: https://www.theguardian.com/ commentisfree/2019/jun/20/four-reasons-why-trump-is-cruising-towards-re-election (access: 28.06.2018)

17 https://www.bbc.com/news/world-europe-48739256 (access: 28.06.2019)

18 Ibidem. 
In Hungary, the government was forced to withdrew financial backing for a festival known for links to extreme-right groups (BAYER, 2019).

The right is certainly resurgent and also has a solid base of support. Both Trump, Orban, and Bolsonaro have had a penchant for picking unnecessary fights. This grabs headlines, shocks, enrages and offends, but this does not solve problems but it is a tactic.

Populism is a democratic reaction to the failures, corruption and cowardliness of the traditional political class. The crisis is how the positive populists can shape and inform the future of a healthy political culture. The demos is not crazy but angry and still searching.

Paul D. Scott currently lives in Paris, after more than thirty years teaching in Japan. He teaches at the Catholic University of Lille. Each year he also conducts a graduate seminar in conflict resolution and mediation at Universitat Jaume, Castelló de la Plana, Spain, as well as an on-line course on democracy and development at the Center for Peace and Conflict Studies at the University of Sydney. He also serves as a translator/interpreter for Hiroshima atomic bomb survivors and is part of a UNESCO project to record these stories. His most recent book is: Peace Democracy Development co-authored with Dr. Johan Galtung.

paulscott1950@hotmail.com

\section{References}

BAYER, L. Orbán government withdraws support for extreme -right festival. In: Politico, June 2019. Last visit on 28.06.2018. https://www.politico.eu/article/viktor-orban-hungarian-government-givessupport-to-extreme-right-festival/

BEREZIN, M. Illiberal politics in neoliberal times: culture, security and populism in the new Europe (p. 304). Cambridge: Cambridge University Press, 2009.

BYRD, D. Apollo and the moon-landing hoax: why do people persist in denying that human beings landed on the moon? In: Human World. 20 July 2018. https://earthsky.org/space/apollo-and-themoon-landing-hoax (Last visit on 28 June 2019)

CAMPBELL, J. W.; Story of the most famous seven words in US journalism. In: BBC News. 10 February 2012. https://www.bbc.com/news/world-us-canada-16918787 (Last visit on 28 June 2019)

CANOVAN, M. Trust the people! Populism and the two faces of democracy. Political studies, vol. 47 (1), pp. 2-16, 1999.

CHATFIELD, T. The Net Delusion: How Not to Liberate the World by Evgeny Morozov - review. In: The Guardian, January 2011. https://www.theguardian.com/books/2011/jan/09/net-delusion-morozovreview (Last visit on 28 June 2019)

CONFESSORE, N.; YOURISH. K. \$2 Billion Worth of Free Media for Donald Trump. In: The New York Times. 15 March 2016. https://www.nytimes.com/2016/03/16/upshot/measuring-donald-trumpsmammoth-advantage-in-free-media.html (Last visit on 28 June 2019) 
DAHL, R. A. Democracy and its Critics. Yale University Press, 1989.

DAIGLE, B. Switzerland: The Ultimate Democracy? In: The National Interest, September 2014. https:// nationalinterest.org/feature/switzerland-the-ultimate-democracy-11219 (Last visit on 28 June 2019)

DE LA TORRE, C. Populism and the politics of the extraordinary in Latin America. Journal of Political Ideologies, vol. 21(2), pp. 121-139, 2016.

GOODWIN, M. New Report: The Rise of Populist Extremism in Europe. Chatham House, 2016.

GRIGONIS, H. Social (Net)Work: How does social media influence democracy. In: Digital Trends (21 March 2018).

HABERMAS, J. Structural Transformation of the Public Sphere. Cambridge: The MIT Press, 1989.

HIRSCHFELD DAVIS, J.; ROSENBERG, M.). With False Claims, Trump Attacks Media on Turnout and Intelligence Rift. In: The New York Times. Archived from the original on March 14, 2017. January 21, 2017. https://www.nytimes.com/2017/01/21/us/politics/trump-white-house-briefing-inaugurationcrowd-size.html (Last access on 28 June 2019)

HOLLYER, J.; ROSENDORFF, B. P.; VREELAND, J. R. Fake news is bad news for democracy. In: The Washington Post (2 April 2018)

MADISON, N.; KLANG, M. Journal of Resistance Studies. Vol 5, n. 1, 2019. https://resistance-journal. org/ (Last visit on 28 June 2019)

MOROZOV, E. The Net Delusion: The Dark Side of Internet Freedom. New York: Public Affairs. 2011.

MUDDE, C., \& KALTWASSER, C. R. Populism: A very short introduction. Oxford University Press, 2017.

. (Eds.). Populism in Europe and the Americas: Threat or corrective for democracy? Cambridge University Press, 2012.

NOLAN, B. Symposium 2016-2017: Globalisation, Inequality and the Rise of Populism: Globalisation, Inequality and Populism. Journal of the Statistical and Social Inquiry Society of Ireland, vol. 46, pp. 110-117, 2017.

OGDEN, S.; HARTFORD, K.; SULLIVAN, N.; ZWEIG, D. China's Search for Democracy. Abringdon: Routledge, 1992.

PASQUINO, G. Populism and democracy. In: Twenty-First Century Populism (pp. 15-29). London: Palgrave Macmillan, 2008.

PASTOR, L.; \& VERONESI, P. Inequality aversion, populism, and the backlash against globalization (No. w24900). National Bureau of Economic Research, 2018.

PIKETTY, T. Brahmin Left vs Merchant Right: Rising Inequality and the Changing Structure of Political Conflict. In : WID. World Working Paper, 7, 2018. http://piketty.pse.ens.fr/files/Piketty2018.pdf (access: 28.06.2019)

ROSANVALLON, P. How to create a society of equals: Overcoming today's crisis of inequality. Foreign Affairs, vol. 95, p. 16, 2016. https://www.foreignaffairs.com/articles/2015-12-14/how-create-societyequals (access: 28.06.2019)

ROSENFELD, M. Review: Extremist Speech and the Paradox of Tolerance. In: Harvard Law Review. 100 (6): 1457-1481. April 1987. doi:10.2307/1341168.JSTOR 1341168.

SCHMIDT, B.; FENG, V. China's Powerful Surveillance State Has Created at Least Four Billionaires. In: Bloomberg, February 2019. https://www.bloomberg.com/news/articles/2019-02-21/big-brotherbillionaires-get-rich-as-china-watches-everyone (Last visit on 28 June 2019) 
VALE, H. F. do. Bolsonaro's approval rating is worse than any past Brazilian president at the 100-day mark. In: The Conversation, April 2019. https://theconversation.com/bolsonaros-approval-rating-is-worse-thanany-past-brazilian-president-at-the-100-day-mark-115617 (Last visit on 28 June 2019)

ZAKARIA, F. The rise of illiberal democracy. In: Foreign Affairs, vol. 76, p. 22, 1997. https://www. jstor.org/stable/20048274 (access: 28.06.2019)

Texto recebido em 10/06/2019

e aprovado em 27/07/2019. 